\title{
The Form of Life of Sanctity in Music Beyond Hagiography: The Case of John Coltrane and His "Ascension"
}

\author{
Gabriele Marino $^{1}$ (D)
}

Accepted: 29 January 2021 / Published online: 16 February 2021

(c) The Author(s) 2021

\begin{abstract}
The paper investigates the cultural unit of "sanctity" in the light of the notion of "form of life", in order to show how jazz master John Coltrane (1926-1967) pursued sanctity as a regulative model with regards both to personhood and musicianship, so as to translate his existential quest into music. Firstly, the paper briefly summarizes: what we mean today by sanctity (focusing on Catholicism and distinguishing between a traditional view and a contemporary, post-Conciliar one); what are the relationships interweaving music and sanctity (the latter mainly providing the former with imagery and narrative - e.g. hagiographic_-model); what we mean by form of life-a notion (Lebensform) brought into philosophical discourse by Ludwig Wittgenstein-in semiotic terms (Jacques Fontanille) and why we can apply it to sanctity. Afterwards, the paper addresses Coltrane's musical career, relying both on hagiographic discourse built around him (e.g. John Scheinfeld's documentary Chasing Trane, 2016) and his discography, with special focus on three game-changers among his albums: Giant Steps (1960), A Love Supreme (1965), and Ascension (1967, published posthumously). Coltrane headed a twofold conversion: he abandoned his native Methodist faith to embrace a personal form of syncretic pantheism; he abandoned the language of traditional jazz to embrace the avant-garde technique of modal composition (in the line of George Russell, Bill Evans, Miles Davis) and the once despised free jazz (Ornette Coleman). Not only Coltrane wanted to be a saint, not only was he regarded as such to the extent that a "St. John William Coltrane Church" was established in San Francisco (by 1969, with official recognition in 1982), but he tried to be one through music; namely, by conveying his spiritual journey via sonic means: proposing a musical catechism (Giant Steps), a musical mass (A Love Supreme), and his own mystique (Ascension). Consistently with the process of selection any saintly figure-and mystiques especially_undergoes in order to be canonized stricto sensu, only some tokens within Coltrane's body of work were included in the canon (both of the musical and religious kind), while his later works were left out due to their radicalism.
\end{abstract}

Gabriele Marino

gabriele.marino@unito.it

1 University of Turin, Turin, Italy 
Keywords Form of life $\cdot$ John Coltrane $\cdot$ Music $\cdot$ Sanctity $\cdot$ Semiotics

Ennosuke Saito: "You Would Like to be a Saint, Uh?."

John Coltrane: [Laughs] "Definitely."

Coltrane in Tokyo, July 9, 1966. [9: 270]

"Yes, I think the music is rising, in my estimation, it's rising into something else, and so we'll have to find this kind of place to be played in."

Coltrane according to Rev. Franzo Wayne King.

"F-A flat, F-B flat."

Coltrane's Acknowledgement (from A Love Supreme), 1965.

\section{Martyrs and Beyond: Sanctity in Christianity}

Sanctity is generally regarded as a key feature of Christian religion and, especially, Catholicism, since saints do pervade its history, imagery, and multimodal textuality (oral stories, written texts, works of art, toponyms etc.). In fact, sanctity was an innovation, though an early one, that shook the original focus of the cult, namely the faith in Christ as the son of God who died and resurrected so as to rescue humanity from its sins. During the persecutions faced by Christians since the first century $\mathrm{AD}$, local communities started honoring those who preferred to sacrifice their own lives rather than betray their faith and survive, to the extent that they became object of worship. These martyrs, the "witnesses [of faith]", became the first saintly figures acknowledged within Christianity, being handed down, since the fourth century, through lists, calendars, and martyrologies (the earliest examples of hagiography, "the writing of the lives of saints") so as to be celebrated all along the year, according to their dies natalis (the day when they sacrificed their life and were born to a new life in Christ) [26]. Saints were regarded as the defenders, the champions, or the heroes of Christianity [16] and the intercessors between the believers and God [5], as they embodied, due to their human nature, a relatable imitatio Christi (imitation of the Christ) and, thus, a much more relatable model of conduct than Christ himself; in such a way, they became the most powerful medium, "the device, the mechanism of mediation" of Christianity [24].

Up to 1200 , this subject matter was not centrally administrated by the Church of Rome nor was formalized as regards the process through which someone could be considered as a legitimate object of cult. Saints, therefore, proliferated across local communities, which often ended up worshipping figures with dubious historical profiles or even completely made-up ones. During the Reformation, both Protestants and high exponents of the Roman Church agreed in considering sainthood an issue: the former as it constituted a form of subsidiary, polytheist-like idolatry and the latter as it destabilized the dogmas and policies of the Church. The field needed to be normalized: both theologically and dogmatically (sanctity stricto sensu) and politically, socially, and culturally (sainthood); both single figures had to be reviewed, 
questioned, and literally rewritten and the general criteria according to which one would be defined as a saint had to be judicially established [7]. By the times of the Counter-Reformation in the second half of sixteenth century, sainthood was subjected to a process of increasing centralization and formalization, so that a specific "court", the Congregatio Rituum (the Congregation of Rites), was created in Rome with the aim to establish which figures would be officially recognized as saints through a proper judicial process. At the same time, due to the long-term end of persecutions, martyrs were no more regarded as the only saintly figures, being joined by other categories of notable examples of Christian conduct and among them the confessors: those who did not die for the Christ, but rather lived for him, exercising their virtues to a heroic degree during their earthly existence. A key figure in the process of systematization of this subject matter was Prospero Lambertini (1675-1758, who became Pope as Benedict XIV from 1740 to 1758) with his treatise De Servorum Dei Beatificatione et Beatorum Canonizatione ('On the Beatification of the Servants of God and the Canonization of the Blesseds'; published between 1734 and 1743). The revision of hagiographic literature due to the Bollandists, a group of Jesuit scholars named after their inspirator (Belgian hagiographer Jean Bolland, 1596-1665) and their Acta Sanctorum ('The Register of Events of the Saints'; 53 volumes issued between 1643 and 1794) was as much as fundamental. ${ }^{1}$

In coincidence with the Second Vatican Council (1962-1965), sanctity underwent an opposite process which led to increasing decentralization and secularization: the model of sanctity promoted by the Roman Church was no longer the herosaint only, but also the everyday person living their life as a continuous testimony of faith, according to the Christian principles. Many official texts of the Roman Church were revised in order to convey this new epistemology; eventually, also the Martyrologium Romanum ('Roman Martyrology'; first officially issued in 1584), a liturgical book generally regarded as the canon of Catholic saints, which was published in a completely new edition in 2001 and 2004 [26]. New types of hagiographies were realized as well; the most prominent example is the Bibliotheca Sanctorum (12 volumes, plus 4 volumes of apparatuses) published between 1961 and 2013 under the auspices of the Vatican, which for the first time proposes sanctity as the object of culturological interest (besides the traditional devotional one) and organizes the subject matter not according to the traditional calendar order, but rather to an alphabetical, encyclopedic one.

\section{Pop Icons as Martyrs: Sanctity Beyond Christianity}

Despite the complexification and stratification of sanctity as a subject matter within Christianity and Catholicism in particular, the traditional conception of the saint was codified and crystallized both within Christian popular imagery and, metaphorically, beyond its original religious semiosphere, within the wider secular culture. The characterizing features of the saint-as-a-martyr, typified by a specific set of

\footnotetext{
1 The best introduction to the field of study of sanctity from a historical perspective is [3].
} 
narrative structures (the tension towards the transcendence of human limits and the role of death in determining the positive, final Sanction), ${ }^{2}$ generated by a specific set of semantic categories (endurance, extraordinariness, and self-sacrifice), were transposed so as to create "popular cults" $[4,6]$ at the center of which stood "cultural saints" [21: 447-448]. Iconic figures, celebrities, or stars ranging from politics (Ernesto Che Guevara), to sport (Diego Armando Maradona), cinema (Rudolph Valentino, James Dean), and music (Elvis Presley, the so-called "other Jesus", or Claude François) are the object of a more or less formalized veneration ${ }^{3}$ not according to the "everyday" ideal of sanctity promoted by the 20th-century Catholic doctrine, but rather to the stereotyped figure of the hero-saint.

With regard to music, religion provides not only a rich imagery or architext, a basin of available semiotic resources that can be conveyed through iconography (e.g. Jim Morrison's most famous picture portrays him as crucified-like), lyrics (Christian rock, Christian metal, Christian dubstep etc.), and, obviously, stylistic features (connoting a given piece of music as "sacred"), but also a powerful narrative framework, of the explicative kind (a meta-text), both to the aesthetic outcomes and the biographical profile of musicians. In other terms, hagiography has literally degenerated; it has been elaborated in contexts and textual genres different from the original ones. Whereas the 20th-century musical avant-gardes were often regarded as "ascetic" [33], at least since the works of French philosopher Edgar Morin in the mid-1950s [29] the analogy between saints and stars became a consumed trope within pop culture [35], to the extent that not only one can find religious parallels drawn in a text about a particularly iconic musician, but also references to rock music mythology in a brief reference book about sanctity:

Today, the cult of celebrity repackages charisma as a form of commoditized Schadenfreude, hoisting pop stars, sportsmen and -women, and movie idols up on pedestals only to bring them crashing down as the often tragic consequences of their lives of excess and transgression play out. A curious parallel exists between the frequent death of young saints at the age of twenty-four, and the likes of Janis Joplin, Jimi Hendrix, Jim Morrison, Kurt Cobain, and Amy Winehouse, all known for their tragic early deaths as members of the ' 27 Club' [41: 146].

For musicians, just like for Catholic saints, the unavoidable viaticum (path) to eternity seems to be represented by death, generally tragic and premature; the former may struggle against substance abuse and fame, just like the latter against sins and persecutions. Death seems to legitimize the (retrospective) interpretation of the musicians' life through hagiographic narrative structures and semantic categories, so that:

\footnotetext{
${ }^{2}$ Capital letters highlight terms included in the technical lexicon of Greimassian semiotics; see [19].

3 This is the case with legendary football player Maradona (1960-2020), to whom a controversial "cult" has been devoted since 1998; see [17: 101-104] and http://www.iglesiamaradoniana.com.ar/.
} 
The dead pop icon becomes much like a saint, especially if they have died due to what appears to be adhering to a rock'n'roll lifestyle. [...] Dying is the ultimate way for a popular music star to be enshrined as a popular music icon, saint or deity. The dead pop star lives forever as a young, brilliant performer at the height of their powers, through recordings and video recordings, validated by the authenticity of believing so much in their music that they effectively died for it [36: 119].

\section{Form of Life: An Embodied Narrative}

"Form of life" (Lebensform) is a term of German language employed in a technical, philosophical sense by Ludwig Wittgenstein in his posthumous works Philosophical Investigations (1953) [39] and On Certainty (1969) [40]. To put it simple, a form of life is the condition of being which makes meaning possible: the rules determining human behaviors can be understood only with reference to a specific form of life, which has determined them in the first place so as they would reflect it. Albeit never thoroughly explained by Wittgenstein, the term has achieved great success in philosophical discourse: it is a notion central to pragmatist philosophy and was recovered, for instance, by Italian critical thinker Giorgio Agamben [1], who traced back a possible genealogy of it in monastic rules. The latest developments of structural-generative semiotics recovered the notion as well; in 1991 Algirdas J. Greimas suggested it as a topic for a seminar, which never took place, and Jacques Fontanille [12] and other members of the Paris School of Semiotics developed it further in journal articles and books. Eric Landowski, among the founders of the sociosemiotic approach, for instance, articulated it as "lifestyle" [22]. Bruno Latour, a philosopher close to French semiotics, talked of "modes of existence" [23]. But the main contribution to a semiotic development of the notion of "form of life", as well as one of the richest developments of the notion in general, has come from Fontanille himself, who has built upon it his ever-growing, complex theoretical system.

According to Fontanille a form of life is the immediate constituent of the semiosphere [15: 260]: "a coherent deformation of the semiotic function" [13: 103; my trans.]; namely, "a coherent deformation that affects all the levels of the generative trajectory of meaning of any discourse or semiotic universe: ranging from sensory and perceptual schemes to narrative, moral and axiological structures" [13: 409; my trans.]. Influenced by the theories of embodiment, ${ }^{4}$ as well as by the reflections of Greimas upon the "aesthesia" [18], Fontanille proposes a development of the narrative theory that links it to body and experience: a form of life is not only the consistency-a

\footnotetext{
4 The theories of extended mind, which include embodiment (or enactivism), were influenced, in turn, by philosophical phenomenology (e.g. Maurice Merleau-Ponty) as they conceive cognition as an activity, rather than a capability, performed not only by the brain but through the whole body as situated in a given environment. The embodiment book which Fontanille references the most is [37].
} 
kind of macro-meta-isotopy (where isotopy means semantic recurrence) - that holds together a given narrative ${ }^{5}$; rather, a form of life is the semiotic norm that pervades and, in the first place, determines such narrative through its enactment, its bodily and existential translation into experience. To live according to a given form of life means to conform to a regulative model of action, to pursue a style "of strategic behavior" [15] aimed at achieving a result which is consistent with the founding axiology. The form of life is exactly such teleological projection from a set of premises to a set of consequences $^{6}$; it is no coincidence that Fontanille has been focusing so much on this notion, as he had already proposed a tensive model of semiotics [11].

\section{Sanctity as a Form of Life: The Embodiment of Christian Faith}

All this considered, sanctity may be legitimately considered as a form of life: its fundamental semantic categories (endurance, extraordinariness, and self-sacrifice) do generate a whole narrative structure (the tension towards the transcendence of human limits and the role of death in determining the positive, final Sanction) and require to be enacted, bodily staged in order to become effective. Sanctity, in other terms, is definitely a narrative, but is also way more than that; according to Massimo Leone: "Saints are important in Catholicism because it is through saints and their representations that the Catholic idea of spiritual achievement can be signified, communicated, and transformed into a practice of life" [23: 2; my emphasis]. In this respect, martyrdom stands as an exemplary type, as it takes an axiology-according to which life is no greater value than faith-to its extreme consequences; death stands as a twofold sanctioning device: it is the final proof of the faith of the martyr and the starting point of the official recognition of the saint as such (canonization is a process which, by definition, starts post-mortem).

As we have seen, the hero-saint whose prototype is the martyr stands as the most productive model both within popular religion beliefs and socio-cultural phenomena, becoming in turn a kind of "Ur-form of life"; a model for other models to be established on the basis of the same regulative principles. Musicians, for instance, may find inspiration in religion and they may be posthumously recognized as martyrs, but they may also explicitly acknowledge such a hagiographic narrative as a regulative model to pursue, by consciously embodying and staging it. More interestingly, they may attempt at translating it into music, not only via paramusical means, ${ }^{7}$ such as lyrics or iconography, but in the very Expression Substance of sound.

\footnotetext{
${ }^{5}$ A narrative generated in the deepest levels of a basic axiology (namely, system of values; the Semiotic square), progressively anthropomorphized and articulated through Semio-narrative (Modalities, Narrative programs, and Actantial roles) and Discoursive structures (Thematization and Figurativization as regards the semantic components; Actorialization, Temporalization, and Spatialization as regards the syntactic components), and superficially manifested in a given text.

${ }^{6}$ In this terms, the form of life may be conceived as what Umberto Eco [10] semiotically describes as ideology.

${ }^{7}$ Musicologist and pioneer of popular music studies Philip Tagg defines "paramusical" - a substitute for "extramusical" - as a dimension including the elements "semiotically related to a particular musical discourse without being structurally intrinsic to that discourse" (https://tagg.org/articles/ptgloss.html\#Param usical).
} 


\section{John Coltrane: Religion as Music, Music as Religion}

John Coltrane is generally regarded as a master of jazz saxophone and jazz music in general and, along with very few other composers and performers (such as Miles Davis), as the plain and simple epitome of the jazzman as a tireless experimenter; even to his own detriment.

Coltrane was born to a Methodist family in 1926 in Hamlet, North Carolina, then a state subject to so-called "Jim Crow Laws", which enforced racial segregation. Also due to the limitations of free speech caused by widespread and institutionalized racism, Methodism has always strictly tied faith and liturgy to musical expression, so that the two things actually overlap: rituals and ceremonies are entirely sung collectively. Since his childhood years, for Coltrane music was the main form for expressing religion and religion could not be expressed through nothing but musical sounds. It is impossible to reconstruct here his entire Bildung, but it suffices to say that, once Coltrane did engage with musical career, in the late 1940s, he engaged with all its flipsides as well; most notably addiction to heroin and alcohol, since a common belief among jazzmen at the time was that they would enhance creativity. Coltrane would later recall this dark period of his life describing himself as a sinner. In 1957 he eventually experienced what he himself defined as a "spiritual awakening", thanks to his wife Naima (Juanita Naima Grubbs; he had married her in 1955), a Muslim believer, and the discovery of Eastern philosophies and religions. Thanks to that, Coltrane got off drugs and embraced a personal syncretic religious view of the pantheistic kind, according to the idea that "there are so many religions: if one is right, the others are wrong" (quoted in Chasing Trane). ${ }^{8}$

Not only since his early years Coltrane was used both to experience and express religion through music, to conceive religion as music, but he also ended up conceiving music as a form of religion, which he believed to and through which he aimed to express the love of God. To Coltrane music meant essentially "uplifting", a call to constant betterment, from the most basic level of musicianship (such as practicing the instrument), to the highest one, that of aesthetic research; Coltrane struggled with his perfectionism and was always unsatisfied about what he had accomplished. As it has been widely noted in literature [32: 781-782], Coltrane's conversion was actually double, as the idea of shifting from solid, well known roots to new forms of experience pervaded him existentially and musically at the same time; not only he abandoned the Methodist tradition but also the traditional language of jazz. Firstly, he experimented the new compositional technique of modality, as opposed to classic Western tonal system. ${ }^{9}$ Then, he embraced the once despised language of free jazz; the "new thing" or "free form", as it was also called, which started off with the album Free Jazz: A Collective Improvisation, issued in 1961 by saxophonist Ornette Coleman [42]. Coleman (1930-2015) was the epitome of unorthodoxy and albeit some considered him as the typical eccentric, misunderstood genius (or, at least, a kind of idiot savant), many simply labeled him a poor musician, whereas not a slob;

\footnotetext{
8 The documentary Chasing Trane is the main subject of par. 6 .

${ }^{9}$ We will delve into modal jazz in par. 7 .
} 
even when complimented, the idea that he was "doing wrong" was predominant. For instance, composer and double bassist Charles Mingus (1922-1979), another master of jazz, is renowned for saying: "It's like organized disorganization, or playing wrong right. And it gets to you emotionally, like a drummer. That's what Coleman means to me". ${ }^{10}$ As many other talented, hyper-technical jazzmen, Coltrane did not acknowledge Coleman's musical revolution at first glance, even though he had become a friend of his. As recalled by Coleman himself:

It took a few years before he really understood what I was playing. Only when he recorded Ascension did he change his mind. ${ }^{11}$ Just then he sent me a telegram to tell me that he had finally understood my music. He also sent me thirty dollars with the telegram, to show me his appreciation in a tangible way [31: 734, my trans.].

Coltrane was a musical talent, but he was more than that; he was a musical genius in the constant search of something which would enable him to simply "create beautiful music" (McCoy Tyner quoted in Chasing Trane). He mastered the grammar of traditional jazz and, once he had experimented the most advanced new jazz languages (modality, free jazz), he became a leading figure within those fields as well.

Both Coltrane's conversions, the religious and the musical one, concurred to the same goal: translating religion into music, translating music into religion, making one out of the two of them. We may talk of a case of intersemiotic translation or transmutation, according to Roman Jakobson's classic typology [20], or of intermodal translation (transduction); namely, a case in which a given semiotic system (religion, a prominent modeling system, according to Yuri Lotman's semiotics of culture [25]) is translated into another one (music). In fact, we should talk of something different, which we may temporarily call "discoursive" or "figural translation" "12, namely, the translation of one virtual semiotic system into different Substances, where none of them has chronologic, logic, nor ontological preeminence over the others. This would mean that we do not have religion first, on the one hand, and then music, on the other, the latter trying to convey the former; rather, we would have different versions (according to different modes, substances, or media) of the

\footnotetext{
$10 \mathrm{https}: / /$ www.charlesmingus.com/mingus/blindfold-test. In later years Coleman would propose a kind of pseudo-theory to justify his approach to music, which he called "harmolodics".

11 We will delve into Coltrane's album Ascension in par. 9; my note.

12 According to the models of the Strata (stratification) of sign by Louis T. Hjelmslev, as integrated in the Generative trajectory of meaning systematized by Greimas in his Dictionary (originally published in 1979) [26], Discourse is the dimension of Content which is impassible to the change of Matter so that it can be expressed through different Substances (Formed matter). Religion, conceived as Discourse, thus includes practices, written texts, visual ones etc. The Figural dimension - not to be confused with the Figurative one (which refers to the passage, within the Trajectory, from Actantial roles to Themes and then, precisely, Figures; namely, identifiable objects of the phenomenic world) - has to be meant as the dimension of conversion from the Plastic level of expression to Enunciation and Discourse, so that it constitutes the synesthetic device that holds together the different semantics of the possible Object-semiotics involved. We may attempt at suggesting that the Figural device which may synthesize Coltrane's form of life (his embodied narrative, his existential and musical Discourse in one) would be the "uplifting".
} 
same semiotic system (the very form of life). Coltrane does not aim at conveying only the authenticity of musical expression, on the aesthetic level, but rather the authenticity of being, on the utopian-existential level. ${ }^{13}$ The idea is that Coltrane would not play music, but rather "he played life" (Carlos Santana quoted in Chasing Trane).

Besides the possible choice between one semiotic category and the other, it is a fact that Coltrane's music constantly aims at talking about something which is not only of the musical kind. To do so, he employs paratextual apparata so as to convey paramusical-i.e. "real life"-meaning; a case in point are "talking titles", the aim of which is to make the meaning or even the specific referent of a given piece of music explicit. For instance, instrumental tune Alabama, included in Coltrane Live at Birdland (1964, Impulse!) [45], was written in response to the $16^{\text {th }}$ Street Baptist Church bombing occurred on September 15, 1963 due to a Ku Klux Klan attack in Birmingham, Alabama, that caused the death of four African-American girls. Anyone familiar with the expressive stylemes (stylistic features) of Western music and jazz music would feel the gloomy, grim tone of the tune, which the title helps amplifying and situating, as it was common, for instance, in so-called program music (instrumental music with a narrative attached via the paratextual means of concert or programme notes).

\section{Chasing Trane: A (Selective?) Hagiography}

Considering Coltrane's above briefly sketched biographic outline, it is no surprise that his life has been generally re-framed in the form of hagiography. As a recent, notable example, one may take John Scheinfeld's Chasing Trane: The John Coltrane Documentary (2016) [53]: the construction of Coltrane's life as a narrative of sanctity is so evident that both positive and negative reviews of the film addressed it. The film reconstructs Coltrane's biography and aesthetics resorting to a series of interviews with prominent musicians who were close to Coltrane or were strongly influenced by his music, so as to depict him as both "an artistic genius and a spiritual giant", in the words of American philosopher and public intellectual Cornel West (b. 1953). Saxophonist Jimmy Heath (1926-2020) describes Coltrane's as "heavenly sound". Living legend Sonny Rollins (b. 1930), another key figure in the evolution of saxophone language in jazz, claims that Coltrane had to "be touched by... the supreme whatever" to sound that way; he was "a great prophet", who was "on a mission, [...] on duty". Wynton Marsalis (b. 1961), perhaps the greatest "neoclassical" jazz trumpeter to date (a kind of caretaker of jazz orthodoxy), says that "Coltrane strength of character is in his own journey through music: he sacrificed himself. And he had the insight and the consciousness to touch that thing that's inside all of us". Coltrane is depicted as a missionary martyr: he sacrificed his life in order to spread the Good News of his own personal Gospel.

$\overline{13}$ For a semiotic typology of musical authenticity see [27: 137-140]. 
Coltrane's apprenticeship, his "training to become Trane" if you will, is interpreted as what Greimas, within his Canonic narrative schema model [19], called the subject's Competence; before getting to the Performance through which they may obtain their junction with the Object of value, the Subject needs to acquire the prerequisites of action, expressed in the form of four main types of Modalities: wanting-to-do, having-to-do, knowing-how-to-do, and being-able-to-do. In our terms we may identify a series of Helpers who facilitated such acquisition: Charlie Parker (1920-1955), who provided the first role model (just like Jesus for any saint) for young Coltrane, who was struck by a concert of his in 1945; Dizzy Gillespie (1917-1993), Miles Davis (1926-1991), and Thelonious Monk (1917-1982), the great jazz masters within whose bands Coltrane served as saxophonist between the early and the late 1950s. As provided for by the Actantial model, some of these Helpers may serve also as Opponents; in particular, Davis, with whom Coltrane collaborated for two non-consecutive times and whose band he eventually left, being convinced that the great trumpeter would have never made it possible for him to fully express himself. In Greimassian terms the Sender of this whole Narrative program cannot be nothing but God themselves, the great inspiration to Coltrane's quest: "In gratitude, I humbly asked to be given the means and privilege to make others happy through music" (quoted in Chasing Trane).

The hagiographic pattern is loud and clear; and, yet, it is only partial. As a matter of fact, just a few minutes from the end of the film, Dr. West basically dismisses a whole entire part of Coltrane's career and aesthetic; the final one, his final years of music:

You know, I don't understand it. I'm open to it. I try to embrace it. I try to follow it. But it's not the kind of, uh, music I would just sit there and listen to all the time. I got to really gotta zero in, and I still don't fully grasp what's going on.

\section{Giant Steps: A Catechism of Modal Techniques}

In 1960 Coltrane releases his debut for Atlantic Records, Giant Steps [43]. This work embodies an overturn in the imitation pattern: once Coltrane was an imitator (of Parker), now he proposes himself as a model or, at least, now he is considered as such. The whole album is largely regarded as a kind of handbook or catechism and the title-track in particular is considered an initiation rite-something that has to be achieved in order to prove the acquisition of competence-for any jazz player worthy of the name.

In 1959 Coltrane had played a key role in Miles Davis' masterpiece Kind of Blue [51], almost unanimously considered as the jazz album par excellence; mainly due to pianist Gil Evans (1912-1988), it was entirely based on modality, a new conception of musical composition originally elaborated by pianist George Russell (1923-2009), different from classic Western tonality, as it was not based on scales (relying on one tonic, the tonal center), but rather modes (such as the Lydian, thoroughly explored by Russell [34]), which granted both new rules and new spaces 
of freedom. Coltrane got intrigued by this avant-garde take on jazz and embraced it so as to pursue his main goal: the constant experimentation of new ways of expression through music. Apparently a simple tune, Giant Steps, the title-track, is in fact extremely challenging even for extremely skilled musicians, as it is constructed according to a proper mathematical-geometrical scheme (which Coltrane had himself handwritten ${ }^{14}$ and implies an advanced mastering of a new conception of motion (modulation) within different systems of notes; the theme has been effectively compared to "uttering a given sentence picking a different language for each and one word" (whence the "gigantic steps", between one system and the other, alluded in the title). ${ }^{15}$ Before Giant Steps, Coltrane was already regarded as a new great saxophone player in the jazz scene; after it he became in turn the new prominent role model for any saxophone player to-be. The balancing of elements that bless Giant Steps with a rare capability of holding together musical pleasantness, theoretical experimentation, and refined musicianship made it the very first Coltrane's "miracle" [30].

Later in 1960 Coltrane releases My Favorite Things, always on Atlantic [44]. The record is devoted to cover versions of standards and among them the title-track, taken from Rodgers and Hammerstein's musical The Sound of Music (1959). Coltrane's version is remarkable for many reasons: it will be his most successful commercial hit to date; it features, for the very first time for him, the use of soprano, a type of sax generally neglected as solo instrument (with notable exceptions such as Sidney Bechet and Steve Lacy); it features a particularly expressive interpretation wherein the sounds produced by the instrument are almost pushed over the edge of noise (at the same time maintaining softness in the delivery); it does so by intervening upon a culturally shared reference that is a very simple musical text, which may be compared to a nursery rhyme (the idea of creating complexity out of simplicity will be a signature of his later production as well).

Both Giant Steps and My Favorite Things perfectly represent the capability of Coltrane to explore the boundaries of musical research without disregarding the need of conveying emotions and communicate them to a potentially wide audience.

\section{A Love Supreme: A Mass in Jazz}

In January 1965 Coltrane releases A Love Supreme (recorded on December 9, 1964), for Impulse! Records [46], which would become one of the most celebrated records in jazz history; probably the only other jazz record par excellence along with aforementioned Davis' Kind of Blue. It is actually peculiar that an album of this kind has achieved the status of classic, as it is a very difficult album from many perspectives.

\footnotetext{
14 http://www.openculture.com/2017/04/the-tone-circle-john-coltrane-drew-to-illustrate-the-theor y-behind-his-most-famous-compositions-1967.html.

15 Quoted in the video The Most Feared Song in Jazz, Explained, uploaded on the YouTube channel 'Vox' on November 10, 2018 (https://youtu.be/62tIvfP9A2w), which provides a short explanation of modal jazz and Coltrane's Giant Steps [24].
} 
The consensus upon this work was and is almost unanimous and, exactly for this reason, it is of great interest to come back to what is perhaps its earliest hostile review, written by music critic Ian Breach on "The Guardian” (August 9, 1965):

There is natural limit to the intensity with which a musician may convey an idea and John Coltrane seems to have overstepped it. He has conceived the idea of devotional modern jazz which on its own terms is as intense form as there is, but his execution of the idea is earnest to the point of being harrowing. After wading through his tortuous confessional on the sleeve and suffering repetitive incantation of the title words during the first track of A Love Supreme (HMV mono CLP, 1869; stereo CSD 1869) one is presented with an exercise in musical monotony. There are good ideas to be heard floating freely, but it is the poor ones that are pursued to the bitter end and beyond. On My Favourite [sic] Things (Atlantic mono ATL 5022; stereo SAL 5022) in which the title number runs for about three times as long as it need, there are patches of relief especially on Ev'ry Time We Say Goodbye and But Not for Me. Combined with the better parts of A Love Supreme, this might have made one good album. As it is, Coltrane exhausts his material and his listeners. ${ }^{16}$

To sum it up: A Love Supreme is way too a personal work (the tortuous confessional of the sleeve) that oversteps the limits of intensity with which a musician should be allowed to convey a musical idea of theirs (the result is obsessive). What in Breach's review is valorized negatively may be nevertheless used to get access to this work of art under an oblique perspective: this is way too a personal work and it is pervaded by repetition and monotony. The album aims to convey the idea of obsession, struggle, and constraint; the idea that, by listening to it, "your body is doing something your mind doesn't want to", such as crying (Carlos Santana quoted in Chasing Trane).

Musically denoted by the usage of modal structures, A Love Supreme is a one-ofa-kind oeuvre in jazz history for many reasons. It is what in rock music is generally defined as a concept album; if not a narrative proper, at least it aims at developing some key ideas, explained verbally through the liner notes, which are unusually long for a jazz record (a similar case may be Mingus' The Black Saint and the Sinner Lady, 1963 [52]): "This album is a humble offering to Him. An attempt to say 'THANK YOU GOD' through our work, even as we do in our hearts and with our tongues. May He help and strengthen all men in every good endeavor", Coltrane writes. This idea of thanksgiving is conveyed both via paramusical and musical means; the album opens with a ceremonial gong and the four tracks, named with what we have defined as talking titles (side one, two tracks: Acknowledgement and Resolution; side two, two tracks put together into a seamless segment: Pursuance/Psalm), are to be meant as the four parts of a circular rite, a kind of mass, featured by continuous musical cross-references.

A Love Supreme features notable examples of "talking sax", sax mimicking the human voice; this happens after the second half of the first track, Acknowledgement,

16 https://www.theguardian.com/music/2017/aug/09/john-coltrane-love-supreme-review-1965. 
in a section (min. ca. 04:55-06:02) where Coltrane's sax simulates the prosody of the sentence "A love supreme" ("a-love su-preme", F-A flat, F-B flat; a motif already introduced at min. ca. 00:33 as a syncopated ostinato of the double bass), and it constitutes the whole musical specimen of the last track, Psalm, wherein the sax "reads" the lyrics included in the liner notes: "I will do all I can to be worthy of Thee O Lord. It all has to do with it. Thank you God. Peace. There is none other. God is. It is so beautiful. Thank you God. God is all. Help us to resolve our fears and weaknesses. Thank you God. In You all things are possible" etc. The mantric pacing of the sax is reinforced by another unusual insertion of the verbal domain for jazz music: towards the end of the first track, Acknowledgement (min. ca. 06:04-06:41), the sax disappears and we can hear Coltrane and the members of the band singing repeatedly "a-love su-preme". Acknowledgement is a track that testifies the best Coltrane's interest in pushing the expressive limits of the instrument (as seen in $M y$ Favorite Things); the sounds produced over the saxophone during his solos lap the limits of noise (a first peak may be found at min. ca. 02:32). The obsessive exploration of the simple four-note cell "a-love su-preme" (F-A flat, F-B flat), pursued all over the track, transposed on different starting notes, gradually moves away from the original tonality (at times denying it entirely), building a musical path that perfectly expresses the experience of spiritual elevation (and finding oneself, after getting lost) that is at the heart of the entire album. Coltrane is interested not in showing a static result, but rather a dynamic process, not in producing enunciates, but rather enacting enunciation, not making the listener hear "played music", but rather musicin-the-making; just like prominent Post-Impressionist painter Paul Cèzanne, with his obsessive research on the subject of Mont Sainte-Victoire, "wanted to depict matter as it takes on form" [28: 13], according to French philosopher Maurice MerleauPonty. ${ }^{17}$ The attempt at creating a semiotic world wherein music, words, and religion converge into a whole is pretty resounding; it is the second musical miracle performed by Coltrane, which earned him the title of musical saint. According to Wynton Marsalis, A Love Supreme is "mythic because of the sacrifice involved" (quoted in Chasing Trane). ${ }^{18}$

\section{Ascension: A Mystique in Free Form}

After his conversion to free jazz Coltrane recorded the music which would be included in his last records, most notably Ascension (1966) [47], Meditations (1966) [48], and Expression (1967, the first posthumous one) ${ }^{19}$ [49], all released on Impulse!. He had met pianist Alice McLeod (1937-2007) in 1963; she would become his second wife in 1966 (thus becoming Alice Coltrane) and, along with

\footnotetext{
17 Merleau-Ponty's essay was originally published for the first time in 1945.

18 It is impossible here to take into account all the musical strategies put in place by Coltrane. The purpose of this article is not to analyze his music in musicological terms, but to show how he built a stratified semiotic discourse that music aimed at translating into sounds.

19 Coltrane died on July 17, 1967; the record was released in late September.
} 
other musicians such as saxophonists Phaorah Sanders (b. 1940) and Archie Shepp (b. 1937) and drummer Rashied Ali (1933-2009), she would strongly influence this phase of Coltrane's career. This new "free form" aesthetic, which would later become more and more connoted by a cosmic atmosphere (the musical double of Coltrane's pantheism), is exemplarily synthesized since the very first moments of Ascension, consisting in a single, long, "big band" composition split to fit the two sides of the vinyl. While the influence of Coleman's Free Jazz is clear, Coltrane succeeds in conveying his spiritual messages through instrumental music by proposing a series of moments which may hardly be considered as interweaved one to the other into a coherent structure, but still they end up bringing the listener into a crescendo: a perfect aspectual dimension and tensive semiotic device to allude to transcendence. In Ascension and in his last works Coltrane seems to be mystically chasing a direct relationship with the Absolute, discarding any traditional form of mediation (namely, moving outside the traditional grammars of jazz), by researching musical abstractness through the violent sublimation of the material, textural concreteness of sound. Such resulting "timbric orgy" is an ablution in chaotic musical magma.

As noted by Italian musician and semiotician Michele Pedrazzi:

The emblematic track The Father, the Son and the Holy Ghost (from Meditations, 1965), ${ }^{20}$ strongly fragmented in the rhythm, gives free rein to all the musicians involved in the performance, who are allowed to overlap one to the other and are given no specific harmonic limits. The idea is that of a nervous, restless texture, without any proper phrasal construction. Against this background, Coltrane intones a theme with all his sonic power: three bare, basic notes (the first three from the rhyme Brother John [Frère Jacques; Fra' Martino, in Italian]), strained and repeated with obstinacy. No one can escape the symbolism of the number three summoned here. No one can escape the sidereal distance with any other work of sacred music known in the West. As in Dear Lord (1965), ${ }^{21}$ we have three notes that rise on a scale, each held for four measures. So much simplicity is in itself a courageous gesture, which perfectly embodies the strength, concentration, purity, painful sincerity of Coltranian music [30: 6-7, my trans.].

Coltrane seems to have become more and more "uncatchable" to many, including many among his historical fans and supporters; talking again about transmutation or transduction (translation between different semiotic systems), it has to be noticed that in this period his public iconography changes accordingly. This is particularly evident in the picture used as the cover artwork of Meditations, a photography shot by Charles Shabacon during a moment from a live performance where Coltrane and double bassist Jimmy Garrison are portrayed in a blurry, dark ocher hue. This visual rhetoric was actually inaugurated back in the early 1960s; a notable example is the picture used as the back cover artwork of the DVD release of the documentary

\footnotetext{
20 The album was recorded in 1965 and released in 1966 [48]; my note.

21 Published in 1970 within the album Transition (Impulse!) [7]; my note.
} 
Chasing Trane: a photo taken during the concert held on 1961 New Year's Eve in Copenhagen, wherein we can see the "aura" generated in the live performance by Coltrane and his band (McCoy Tyner and Art Davis are included in the shot), ${ }^{22}$ in a kind of visual rendition not so different from Expressionism.

\section{St. Coltrane and His Sacred Texts: Canonization as Selection}

Coltrane did die prematurely of liver cancer, at the age of 40, in 1967. As any saint worthy of respect, he was canonized and, being a one-of-kind saint, his canonization was actually threefold; he was canonized at least twice during his life for his musical achievements (he was blessed due to Giant Steps, he became a saint due to A Love Supreme) $[30,38]$ and he was canonized stricto sensu as a religious saintly figure after his death, even though outside Christianity. The story of this Coltrane's cult is strange, fascinating, and, perhaps, unique [2].

After seeing- "witnessing"-John Coltrane live in concert twice in San Francisco between 1965 and 1966, Los Angeles-raised, son to a Pentecostal minister, jazz enthusiast and saxophone player Franzo Wayne King and his wife to-be Marina felt their life had changed forever: they experienced what they would later regard as a "Sound Baptism". Immediately after Coltrane's death, King founded a music venue where to express his musical veneration for him and jazz music in general, "The Jazz Club", which would be renamed the "Yardbird Club", after Charlie Parker's nickname, the next year (1968). In 1969 King turned the club into an actual house of worship, the "Yardbird Temple": Parker was John the Baptist, Coltrane the God incarnate. Eventually renamed the "One Mind Temple" in 1971 and strongly connected with the Black Panther Party for all the mid-1970s, the cult became more and more institutionalized; in 1982 it was incorporated by the African Orthodox Church (founded in 1921 within the black Episcopalian community and expelled from the Christian communities in 1938) under the name "St. John William Coltrane Church", and Coltrane was eventually converted from deity into "simple" patron saint. As of today, this San Francisco religious and artistic community has its own bishops, priests, and deacons, it lays strong emphasis on apostolic succession and celebrates the seven sacraments of the Roman Catholic Church; its worship is liturgical (both of Eastern and Western rites) and the Nicene, Apostles', and Athanasian creeds are affirmed. ${ }^{23}$ Within Coltrane Church's fluvial jam session-like liturgy A Love Supreme plays a key role in the respect of being regarded as the main sacred text; on the contrary, none of Coltrane's subsequent works was granted such an acknowledgment.

In the documentary Chasing Trane, Cornel West compares Coltrane to Shakespeare and Beethoven, stating that he was both "an artistic genius and a spiritual

\footnotetext{
22 The photo rights are owned by JP Jazz Archive/Redferns; the picture can be publicly accessed free of charge at the following Getty Images webpage: https://www.gettyimages.co.uk/detail/news-photo/photo -of-john-coltrane-1961-11-john-coltrane-mccoy-tyner-news-photo/86113669.

23 https://www.coltranechurch.org/.
} 
giant"; at the same time, his devoted appreciation for his music stops at A Love Supreme, since he would not understand the later aesthetic shifts taken by Coltrane. This apparently strange "censorship" is actually consistent both with the jazz canon, which has never fully metabolized Coltrane's free jazz and cosmic oeuvres (the object of cult to a specialized fandom, even bigger outside jazz) ${ }^{24}$ and with what generally happens to the great saintly figures of Christianity. The idea of an idiosyncratic, non-mediated contact with the Supreme (like the one musically chased by Coltrane throughout his whole life), which is traditionally the idea at the center of mystique as a practice and textual genre (as notably investigated by French Jesuit scholar Michel de Certeau [8]), is self-destructive, on the one hand, and is shocking and potentially dangerous for the institutionalized cult, on the other; as a consequence, the possibility to celebrate officially such saintly figures has to go through a process of selection. In order to be admitted into the canon of exemplary models, in order to become part of the norm, the new saint - and the mystique especiallyneeds to be, at least to a certain extent, regularized, normalized in turn [7].

Coltrane's innovative sacred music was canonized both in music and religion, but only to a certain degree of deviation from the norm: only up to A Love Supreme; whereas his most radical, final outcomes - the ones which would have hopefully granted him the final "ascension"—-did not make the list.

Acknowledgements This paper is part of the research project NeMoSanctI, which has received funding from the European Research Council (ERC) under the European Union's Horizon 2020 research and innovation programme (Grant Agreement No. 757314). The Author would like to thank Prof. Jenny Ponzo for the useful insights.

Funding Open access funding provided by Università degli Studi di Torino within the CRUI-CARE Agreement.

Open Access This article is licensed under a Creative Commons Attribution 4.0 International License, which permits use, sharing, adaptation, distribution and reproduction in any medium or format, as long as you give appropriate credit to the original author(s) and the source, provide a link to the Creative Commons licence, and indicate if changes were made. The images or other third party material in this article are included in the article's Creative Commons licence, unless indicated otherwise in a credit line to the material. If material is not included in the article's Creative Commons licence and your intended use is not permitted by statutory regulation or exceeds the permitted use, you will need to obtain permission directly from the copyright holder. To view a copy of this licence, visit http://creativecommons.org/licen ses/by/4.0/.

\footnotetext{
${ }^{24}$ Popular polls generally do not include Coltrane's post-A Love Supreme albums; e.g. music industry professional and columnist Sam Armstrong's "Best Jazz Albums: 50 Essentials You Need to Hear", published on 'uDiscover' on April 5, 2019 (https://www.udiscovermusic.com/stories/50-greatest-jazz-album s-ever/). Alternative polls, on the contrary, do and, furthermore, include them with very good rankings; for instance, cognitive researcher and cultural historian Piero Scaruffi's 2007 "The Best Jazz Albums" puts Mingus' Black Saint 1st, Coltrane's A Love Supreme 2nd and Ascension 10th, while Davis' Kind of Blue - 1st in the aforementioned Armstrong's - is only 37th (https://www.scaruffi.com/jazz/best1 00.html).
} 


\section{References}

1. Agamben, Giorgio. 2011. Altissima povertà. Regole monastiche e forme di vita. Vicenza: Neri Pozza.

2. Baham, Nicholas Luis III. 2015. The Coltrane Church: Apostles of Sound, Agents of Social Justice. Jefferson NC: McFarland.

3. Gajano, Boesch Sofia. 1999. La santità. Roma and Bari: Laterza.

4. Boudewijnse, Barbara H., and Heimbrock Hans-Günter, eds. 1990. Current Studies on Rituals: Perspectives for the Psychology of Religion. Amsterdam and Atlanta: Rodopi.

5. Brown, Peter. 1981. The Cult of the Saints: Its Rise and Function in Latin Christianity. Chicago: The University of Chicago Press.

6. Browne, Ray Broadus. 1980. Rituals and Ceremonies in Popular Culture. Bowling Green OH: Bowling Green University Popular Press.

7. Dalla Torre, Giuseppe. 1999. Santità e diritto. Sondaggi nella storia del diritto canonico. Torino: Giappichelli.

8. de Certeau, Michel. 1982. La Fable mystique (XVIe-XVIIe siècle), tome I siècle), tome I. Paris: Gallimard.

9. DeVito, Chris, ed. 2010. Coltrane on Coltrane: The John Coltrane Interviews. Chicago: Chicago Review Press.

10. Eco, Umberto. 1975. Trattato di semiotica generale. Milano: Bompiani.

11. Fontanille, Jacques, and Claude Zilberberg. 1998. Tension et signification. Liège: Mardaga.

12. Fontanille, Jacques. 1993. Les formes de vie. Présentation. RSSI-Recherches Sémiotiques/Semiotic Inquiry (XIII) 1-2: 5-12.

13. Fontanille, Jacques. 2004. Figure del corpo: per una semiotica dell'impronta. Roma: Meltemi.

14. Fontanille, Jacques. 2008. Pratiques sémiotiques. Paris: Presses Universitaires de France.

15. Fontanille, Jacques. 2015. Formes de vie. Liège: Presses universitaires de Liège.

16. Brocchieri, Fumagalli Beonio, and Mariateresa and Guido Guidorizzi. . 2012. Corpi gloriosi: Eroi greci e santi cristiani. Roma and Bari: Laterza.

17. Graziani, Graziano. 2018. Catalogo delle religioni nuovissime. Macerata: Quodlibet.

18. Greimas, Algirdas J. 1987. De l'imperfection. Périgueux: Éditions Pierre Fanlac.

19. Greimas, Algirdas J., and Joseph Courtés, eds. 1982. Semiotics and Language. An Analytical Dictionary. Bloomington IN: Indiana University Press.

20. Jakobson, Roman. 1959. On Linguistic Aspects of Translation. In On Translation, ed. Reuben A. Brower, 232-239. Cambridge MA: Harvard University Press.

21. Laderman, Gary, and Luís. D. León, eds. 2003. Religion and American cultures: an encyclopedia of traditions, diversity, and popular expressions, vol. 1. Santa Barbara CAL, Denver CO and Oxford UK: AB-CLIO.

22. Landowski, Eric. 2012. Régimes de sens et styles de vie. Actes Sémiotiques [En ligne] (2012) 115. Available at : https://www.unilim.fr/actes-semiotiques/2647.

23. Latour, Bruno. 2012. Enquête sur les modes d'existence: une anthropologie des moderns. Paris: La Découverte.

24. Leone, Massimo. 2010. Saints and Signs. A Semiotic Reading of Conversion in Early Modern Catholicism. Berlin and New York: Walter de Gruyter.

25. Lotman, Yuri. 1967. Thesis on Art as a Secondary Modelling System [text in Russian]. Signs Systems Studies 3: 325-367.

26. Marino, Gabriele. 2019. Approaching the Martyrologium Romanum. A semiotic perspective. Lexia 2018 (31-32): 175-215.

27. Marino, Gabriele. 2020. Frammenti di un disco incantato. Teorie semiotiche, testualità e generi musicali. Roma: Aracne Editrice.

28. Merleau-Ponty, Maurice. 1964. Sense and Non-Sense. Evanston IL: Northwestern University Press.

29. Morin, Edgar. 1957. Les Stars. Paris: Éditions du Seuil.

30. Pedrazzi, Michele. 2008. Dritto all'anima delle persone. Il discorso sacro di John Coltrane. E/CRivista telematica dell'Associazione Italiana di Studi Semiotici: 1-9. Available at: http://www.ecaiss.it/pdf_contributi/pedrazzi_20_03_08.pdf.

31. Polillo, Arrigo. 1997. Jazz. La vicenda e $i$ protagonisti della musica afro-americana. Nuova edizione aggiornata a cura di Franco Fayenz. Milano: Arnoldo Mondadori Editore.

32. Porter, Lewis, ed. 2013. The John Coltrane Reference. New York and London: Routledge. 
33. Riley, Charles A. 1998. The Saints of Modern Art: The Ascetic Ideal in Contemporary Painting, Sculpture, Architecture, Music, Dance, Literature, and Philosophy. Hanover and London: University Press of New England.

34. Russell, George. 1953. Lydian Chromatic Concept of Tonal Organization. New York: Concept Publishing.

35. Schmitt, Jean-Claude., ed. 1983. Les Saints et les stars: le texte hagiographique dans la culture populaire: etudes. Paris: Editions Beauchesne.

36. Till, Rupert. 2010. Pop Cult: Religion and Popular Music. London and New York: Continuum Books.

37. Varela, Francisco J., Eleanor Rosch, and Evan Thompson. 1991. The Embodied Mind: Cognitive Science and Human Experience. Cambridge MA: MIT Press.

38. Whyton, Tony. 2013. Beyond 'A Love Supreme': John Coltrane and the Legacy of an Album. Oxford UK: Oxford University Press.

39. Wittgenstein, Ludwig. 1953. Philosophical Investigations. Oxford UK: Blackwell.

40. Wittgenstein, Ludwig. 1969. On Certainty. New York: Harper.

41. Yarrow, Simon. 2016. The Saints: A Short History. Oxford UK: Oxford University Press.

\section{Discography}

42. Coleman, Ornette. 1961. Free Jazz: A Collective Improvisation. Atlantic.

43. Coltrane, John. 1960. Giant Steps. Atlantic.

44. Coltrane, John. 1960. My Favorite Things. Atlantic: My Favorite Things.

45. Coltrane, John. 1964. Alabama. Coltrane Live at Birdland. Impulse!

46. Coltrane, John. 1965. A Love Supreme. Impulse!

47. Coltrane, John. 1966. Ascension. Impulse!

48. Coltrane, John. 1966. The Father, the Son and the Holy Ghost. Meditations. Impulse!

49. Coltrane, John. 1967. Expression. Impulse!

50. Coltrane, John. 1970. Dear Lord. Transition. Impulse!

51. Davis, Miles. 1959. Kind of Blue. Columbia.

52. Mingus, Charles. 1963. The Black Saint and the Sinner Lady. Impulse!

\section{Videography}

53. Scheinfeld, John. 2016. Chasing Trane: The John Coltrane Documentary. US. Meteor 17/Crew Neck Productions.

54. The Most Feared Song in Jazz, Explained. Vox November 10, 2018. Available at: https://youtu .be/62tIvfP9A2w.

Publisher's Note Springer Nature remains neutral with regard to jurisdictional claims in published maps and institutional affiliations. 